Journal of Law \& Social Studies (JLSS)

Volume 3, Issue 2, pp 133-142

www.advancelrf.org

\title{
Functioning of Parliamentary Committees in Pakistan: An Analysis
}

\author{
Sidra Akram \\ $\mathrm{PhD}$, Research Scholar \\ Department of Political Science and International Relations, \\ Government College University Faisalabad \\ Email: sidraakram200015@gmail.com \\ Dr. Muhammad Azhar (Corresponding Author) \\ Assistant Professor \\ Department of Political Science and International Relations \\ Government College University Faisalabad \\ Email: muhammad.azhar@gcuf.edu.pk \\ Rizwan Haleemi \\ $\mathrm{PhD}$ Research Scholar \\ Department of Political Science and International Relations, \\ Government College University Faisalabad \\ Email: rizwanhaleemi@gmail.com
}

\begin{abstract}
Parliamentary committees are a tremendous way to ensure predictability and transparency in the work of ministries, regulatory bodies and public sector enterprises via effectual function of oversight. A major challenge for democracies is to ensure good governance especially in changing the way the private sector and the government engages. This research provides a concise and analytical study of the functioning of the system of committees in democratic systems and in Pakistan. The research analyzed the effectiveness of the parliamentary committees which will form the basis for this work for further progress. The research work is analytical as well as descriptive in nature. Data related to this study has been collected by secondary sources such as books, journal articles, encyclopedias and research reports.
\end{abstract}

Keywords: Pakistan, Parliament, Committees function, Oversight

\section{Introduction}

Committees perform a very essential and energetic part of watching in addition to the working of the relevant ministry of the government. In the democratic parliamentary system, committees are considered the brain, hands, ears and eyes of the Parliament with an excellent mechanism that makes sure the predictability and transparency in the functions of regulatory bodies, public sector enterprises and ministries through effectual oversight(Tasleem, 2013).

Over the years, parliamentary committees developed an essential and central part of the legislative system. The Parliament of Pakistan has various committees. However, each of the committees handles a specific area of legislation. However, in the country, the imperative challenge for democracies is to make sure the good governance, when it gives the especial change in a governmental way and private sector connection. Therefore, the legislative committee system described as a method makes a way for the division powers to the specialization and legislative labour. Because members of each committee allotment capability in the arena that is allocated to them. That's why, within the internal parliamentary operations it's considered to be the silver bullet. Generally, the committees are considered as the gatherers of information, shifters of the amendments/alternatives in legislation, refiners of the legislation and the political nerve ends (Raza, 2009). The character of Parliamentary committees is to bit the Parliament's effort and fund professional estimations on rule, to investigate, inspect or scrutinizes the tenet building preferences and of accomplishments strategy creators. Inspection and stability is the most influential principle in this concern (Ahmad, 2017). 
A strong legislative committee system generally boosts up the overall parliamentary performance. It also provides a stance about direction and progress to the legislatures, and empowers the structure to enhance the performance by a clear direction and suitable targets. Committee system plays a major role in modern democracies. Today, it became a greater need for the countries. In order, it became easy to investigate analysis and scrutinize the works of their organizations so that to convinced the outcomes are delivered (Assembly, 2017). Every Parliament is answerable to the electorates about the government agencies and makes sure that how these agencies are performing their jobs well (Valentine, 2010).

In the Parliament, the committee arrangement is a well-organized and competent means of implementing adjustments and maintaining oversight in the agencies working which is controlled through the executive. Specific committees properly do work well in the committee system. Standing committees are an imperative forum for eliminating conflicting interests. However, within a legislature standing committees perform a function to the examination of bills usually line-by-line and detailed (Tasleem, 2013). Therefore, these committees assist the Parliament (which is a sovereign institution in any country) before the House, to make solid decisions through improving and examining proposals. Committees endeavours to oversee the proceedings and actions of the executive departments and their government officials. An excellent example of this is the British House of Commons 'Procedure Committee'. Procedure Committee is responsible for making it sure that appropriate procedure and practices are used in dealing with the public business by the House of Commons (Yamamoto, 2007).

Today, in Pakistan the Committee System is extra operational stronger than previous, especially after 1992. While, Pakistan's National Assembly adopts its Conduct of Business and Rules of Procedure and in 2007 which were improved and amended further. The primary philosophy of the revamped Committee System of National Assembly has been to accomplish the supervision of administration, the role of laws formulation, and pursuit of administration obligations to the electorate that is the three-fold work of other assembly work. The working of the Assembly committees makes it standardized by the Rules 198-245 (Tasleem, 2013). There is so much work to do in the legislature and if they keep all the drafts in view with full detail and gave the required time to each draft then not a third of its work will be completed successfully. This is especially due to the committee system that not only gets the job done quickly but also completes it very satisfactorily. Due to the committees system parliament saves a lot of time and its work is also very effective and useful. It is not the job of the House just as committee members know the details of a draft (Raza, 2009).

The committees have gets excellent research and investigation facilities that can produce better results. Flexibility is found in the committee methods. There are several committees set up in the both Houses of Pakistan. The committees are elected from among the parliamentarians. When a draft reaches the legislature in the House, then after a few steps the draft is presented to a committee, namely introduction and first reading (Valentine, 2010). The committee evaluations the accountants and deputies of the ever submitted draft and with his remarks send the draft back to the House. Unlike the American committees, in Pakistan the committees do not have the influence to eliminate any draft by themselves. The committees must information positive or negative on respectively draft and submit it to the House (Zaka, Green, \& Malik, 2015).

Every Committee consisted upon not more than fourteen members with the total membership of it and elected by the House. The Adviser or Minister will be an ex-officio associate to the concerned Committee, unless he/she is a member of the Senate he will not be enabled to poll as an ex-officio participant. At the same time, a member cannot be a participant of more than 5 Standing Committees. The Committee on Privileges and Rules of Procedure contemplates issues about the conduct of business and its procedure in the Assembly House and arranges the privilege motions stimulated through the followers of the House. According to Rule 163, all other issues such as Committee composition and its election will be governed by the rules of the next standing committee, while the Minister of Parliamentary Affairs will be its former member (Tasleem, 2013).

\section{Composition and Powers of the Committees}

In the legislation process standing committees perform a crucial character in the National Assembly of Pakistan and assist to government by observing and oversight the functioning of the related ministries. The standing committees are authorized via Pakistan's National Assembly to check on public accounts and ministries and are to look after their fields (Valentine, 2010). The committees work according to rules and procedures of the National Assembly, to examine the management, expenditures, procedures and notices of the concerned department and then 
and there onward endorsements and forward to the parliament. The 7 committee has an indefinite chance to effort efficiently. The presiding committee should suggest the leader of the hostility as the chairman of the Public Account Committee for extra pellucidity. All further committees should have equitable illustration in different committees to improve their capability and involvement in the law giving route. Agencies should follow the structure and everybody should be responsible permitting to legal sovereignty and committees should organize additional in this concern. The parliamentary committees on interest must effort extra exposed and general safety issues should be trialed publicly on with a wide range of administration and non-government observers as in National Assembly (Ahmad, 2017).

A Bill or a subject matter related to that bill will be examined by the committee that is mentioned to the committee by the Speaker of House and then put forwards its report with advice or recommendations with surety that the presented bill did not violate the Constitution. A committee can also scrutinize the concerned ministries expenditures, delegated legislation administration etc. However, during the legislative function the committees can also be reviewing the bills, and committees of the both Houses of Senate and National Assembly are authorized to perform some functions which are under the following. Such as, for investigative purposes, summon government officials and witnesses, and the use right of demand from the government for documents. "Therefore, the government reserves the civil rights to declaration concessions/privileges wherever state concern can be conceded" (Niazi, 2013).

These committees within the House reflect the position of the party. Almost all the chairpersons of the committees are always live close to the ruling party. Though recently an allowance in this contract has been changed in Pakistan's Public Accounts Committee by the PPP government in 2011, and now the member from the Opposition Party has been appointed for the chairpersonship of Public Accounts Committee. The respective Houses elects the entire associates of the committees, the parliamentarians are comprised of the committees both from the opposition and the ruling party (Niazi, 2013).

However, committees are the soul of a successful Parliament. Therefore some committees are elected for a short term and after the work for which they are created, they automatically dissolve such as the special and select committees. The same thing applies with the senate committees while the Functional and standing committees are established for the whole duration of the House. Generally, the committees do not give media access or a legal bar to witness the committee proceedings in Pakistan. If the committee does not want to keep its proceedings open to the public and media, then the committee meeting would not be placed in the camera. Parliamentary committees face foremost constraints of resources in Pakistan such as redundant staff and insufficient resources and lack of expert support and advice that hinder their productivity and work (Valentine, 2010). The constitution of Pakistan highlights two core kinds of Parliamentary Committees as modified up to April 2010 and proposed their basic significance. These are the following:

\section{Mediation Committee}

(As the Constitution of Pakistan under Article 71 is mentioned) The Mediation Committee is set up to examine the views of both the houses namely the upper house and the lower house, and to resolve issues with their views. In this committee, both houses of the parliament nominate an eight-member panel to represent their views. If there is a rejection or delay of more than 90 days after any change in the bill, then the concerned parties are contacted by this committee. Then the mediation committee drafts the bill, it will be acceptable to both parties, and after 90 days they will be produced before them separately under Article 71(4). However, the bill was put forward for presidential assent when it gets approval from both houses of Parliament (Valentine, 2010).

\section{Finance Committee}

(As the Constitution of Pakistan under Article 88 is mentioned) Finance Committee within the authorized assumptions controls the Assembly expenditures. The House nominates the Federal Finance Minister and other members of the Finance Committee and the Speaker take the chair or presiding over the meetings of the finance committee. As the name suggests, this committee assumes the jobs relevant to the field of expenditure and finance. The finance committee is required to formulate an effective budget for the country and to promote its traditional significance. The Public Accounts came into being as a result of the finance committee and it is a branch of the sponsorship committee. Hence, the structure and tasks of the funding committee have been formulated by following all the procedures laid down in the text for the Public Accounts Committee (Ahmad, 2017). 


\section{Parliamentary Committees}

Usually, members of the committee have particular interests or knowledge about the issues under their influence and jurisdiction. The legislative committee system monitors the activities of the government, to the House recommend courses of action, to evaluate the information after collection, identify suitable issues for the review of legislation. However, during the era of Zulfikar Ali Bhutto from 1973 to 1977, the number of committees has increased gradually from 6 to 52, so the number is the same as in 2017. Therefore, there are various types of the parliamentary committees. The majority of this committee (thirty-four) is called the "standing committees" and others are called the "functional committees" (Zaka, Green, \& Malik, 2015).

In democracies, most of the legislation is done in committees which consist of about 20 or fewer members and these members are from both the ruling party and the opposition. These committees fully cover the details of new governmental policies, proposed laws or even broader topics such as health and economy and then present their report in the Parliament. Permitting to the "Rules of Procedure" of the National Assembly and its "Conduct of Business 2007" there should be a separate standing committee for each government ministry. Therefore directly while the balloting of the Speaker Assembly; all the committees are requisite to be chosen by the assembly within 30 days. However, it is stated according to the Procedure and Conduct of Business 2007 and Article 88 that also to the "Standing Committees on Public Accounts", Government Assurances, House and Library, Business Advisory _ a Standing Committee will be formed rules of privileges and procedures for each and every government Ministry. But if there is an issue on behalf of which a committee is not selected and assigned in advance, the matter will be taken up directly through the Standing Committee of "Law, Justice and Parliamentary Affairs". Mostly, parliamentary committees are called small legislators or mini parliaments. They are small clusters of legislators which are nominated, constituted and appointed within the legislators which not only help the parliament at the same time to do different things but also give a chance for detailed investigations and discussions on related issues through parliament to reach a real end. "Parliamentary committee system" permits the miniature legislature also to analyze the detailed policy matters. The bills are also scrutinized by the Parliamentary committee system more transparently with extensive and wide brainstorming which was not possible for the intact House (Cheema, 2018).

As per rule 201, the parliamentary committees evaluate the reports on a bill as a prime function, which stuff or issue discussed to them by the Speaker of the House. Then submit reports with suitable recommendations and suggestions to the House. Standing Committees perform a significant role in oversight as permanent nature. It also monitors the functioning and working of the related Government Ministries (PILDAT, 2013). There are several committees as there are ministries in Pakistan. National Assembly committees are classified as the Standing Committee, Mediation Committee, Public Accounts Committee, Committee on Government Assurances, Finance Committee, Business Advisory Committee, House and Library Committee, committees on Rules of Procedure and privileges and some other Committees. Generally, parliamentary committees in Pakistan fall into two types:

\section{Standing Committees}

- Public Accounts Committee

- Committee on Government Assurances

- Committee on Rules of Procedure and Privileges

- House and Library Committee

- Business Advisory Committee

\section{Ad hoc/other Committees}

\section{Standing Committees}

The Standing Committees always perform a precise vital part in observing and supervising the work of the important government offices. It regards the brain, eyes, hands, and ears of the government in parliamentary democracies. A different motto almost the significance of the Committee is that "Congress in session is Congress in Exhibition, while Congress in its Committee Room is Congress at work" (Niazi, 2013).

The standing committees examine the bill coming through one of the two houses and submit it to the house after preparing its report with recommendations and advice. The subject matter of the bill referred to the relevant standing committee. All committees of involved committees are formed to connect to the Federal Government Divisions or the Ministries in the National Assembly. Its roles are to relating arguments on the regulation and control of the routine, development and functioning of the associated Ministries. It has the wide commands deprived of any kind of position 
by the house to pursue proclamation on assurance, requisition observers, the plea for certified registers and begin any problem inside their authority (Chang \& Ramshaw, 2019).

According to the Rules of Procedure of the National Assembly, include special powers for the standing committees to examine the administration, policies of the relevant ministries, public petitions, delegated legislation and expenditures (Mahmood, 2015). Then the committee sends a report of his findings with bits of advice and recommendations to the ministry and its affiliated public bodies. Later the balloting of the leader of the House, it is considered that within 30 days the Assembly selects all the participants of the standing committees and provided a Rule of Procedure. The chairperson of the standing committee cannot elect the parliamentary office assistant or a minister. However, to elect the chairperson of the committees failed by the assembly that means committees will continue non-functional regardless of their suitable development. Among the corporation partners, the dearth of settlement designates the core purpose for the non-election of the commission chairs (CPDI-Pakistan, 2005). The chairperson delight in the several significant privileges that are he or she delivered an administrative center with some special staff, he or she cast the ballot in the event of an equality of polls, as a member his/her vote, and also the presiding officer of a committee chairing in his/her time off. Standing committee contained on the exceptional commands allowing to the expenses, National Assembly authorizes committees to analyze the proxy lawmaking, community strategies and petition, supervision and civic figures that are also linked with it. These allied figures send onward the results, endorsements and intelligences to the related office then this department will conduct this description to the standing committee (Hasan, Hanif, \& Khan, 2009).

Presently, the Assembly has 34 Standing Committees that are the Cabinet secretariat, environment variation, trade, statement, defense, defense manufacture, expert exercise and the central instruction, transfer and measurements, state tradition and communications, Gilgit Baltistan and the Kashmir concerns, Production and Industries, Housing and Works, Revenue, Foreign Affairs, Finance, Professional exercise and Federal instruction, Economic matters, telecommunication and evidence machinery, rule and fairness, internal and sedatives mechanism, national food security and research, general fitness facilities regulations and coordination, fuel and normal properties, development and improvement foreign Pakistan and social supply progress, senatorial activities, spiritual dealings and interfaith coherence, harbors and shipment, railways, the law of measures and honors, knowledge and machinery, aquatic and supremacy, federations and boundary counties, fabric manufacturing. All these committees are as to corresponding one committee for each Ministry of the Government (PILDAT, 2013).

Any matter is mentioned to the relevant standing committee for identification by the speaker of the assembly, after which the members of the committee consider it and read it with an important point of view that appropriate legislation to be proposed or to make workable recommendations or advice to the assembly. However, Article 200 clause 4 formulates some stipulations for the standing committees which are under the following:

- All standard standing committees comprised of an utmost of 20 members within 30 days of the election of the house leader.

- These committees are responsible for the consideration of bills, and issues related to this are examined by the Assembly or the Speaker of the assembly. In addition, the standing committees are responsible for making recommendations and reports on issues of concern. The committee is also responsible for inspecting whether the presented bill is in alliance with the structure or not.

- Notices modifications can be made with recommendations of the committees. However, under normal circumstances, the committee will not have the power to prevent the assembly from considering this issue.

- Though, if the committee remains unsuccessful to make recommendations within the stipulated time, then without waiting further for it the assembly is considered free. Then the matter was considered for removal from the committee.

- The committee will examine the working procedures of all the concerned ministries including passed down regulations, administration, budget allocation, requests by the public and other policies, then suggestions will be provided after with all the collected information.

- Any matter of public interest or any pending business-related matter before the house which falls under the purview of government action will be brought for consideration before the assembly. It is also worth mentioning here that it does not include any case which is related to the court or any other problem which remain unresolved already any court of law.

There are some issues mentioned to the Standing Committees which are following PEMRA presented in 2008. PEMRA transformed into laws on information and broadcasting that was referred to the standing committee. Secondly, ERRA (Earthquake Reconstruction and Rehabilitation Authority) which is the issue of alleged 
misappropriation, it also stated to the standing committee. Thirdly, the issue of mishandling and the issue of alleged corruption on large scale via the "Capital Development Authority" were also cited to the involved committee (Zaka, Green, \& Malik, 2015).

\section{The Public Accounts Committee}

In Pakistan, the Public Accounts Committee was recognized in 1948 and comprises on maximum of 23 members who are elected through the assembly and the minister of finance joined this committee as a member automatically. It is considered the most significant tool for the accountability of legislation. It is recognized at the district, provincial and federal government levels and presenting reports to the head of the district, provinces and state. Allocation of government expenditure, annual financial accounts of the government, report of the Auditor General of Pakistan and such other matters are the basic functions of the public accounts committee (Cheema F. S., 2020). Parliamentary control over public finance is working in the results phase and the proposals phase. The government receives financial approval from public representatives to implement its policies and programs in the first instance. Another phase involves controlling the expenditure of public funds, in which the Public Accounts Committee plays a role in examining federal government accounts. To keep a check on public expenditure to the public representatives assigns the responsibility in this process. For the civilized society, accountability is the reinforcement principle (Sirmed, 2019).

Hence, it is very important for the solidity of the general public that there is a compact structure of liability. The government in all domains considered clearness and Public Accountability as a significant necessity for the actual and accurate supply of community amenities. Public Accounts Committee is the capability of public money that indicates the essential constituencies of the domain of Parliament. The key roles of the Public Accounts Committee are to inspect the AG (Auditor-General) testimony for the distribution, sovereign and semi-autonomous organizations, companies and governments (Sirmed, 2019). It is the constitutional organ of the National Assembly. Beneath the current establishment of Pakistan, such intelligence that is linked to financial records of the federation will be submitted to the chief by the AG (Auditor-General). At that point earlier the senate of Pakistan, the leader will lay to this information. However, Public Accounts Committee performs the following main functions:

- This committee is responsible for the receipt of funds for government expenditure of the assembly, annual reports and scrutiny of the financial statement of government and results of editor broad.

- The committee also ensures that funds provided for precise accounts were lawfully accessible and were allocated for a purpose.

- This committee also examines the P\&L statements of the government. The P\&L consists of the state's expenditure and revenue on government schemes, manufacturing and trade schemes.

- This committee also scrutinizes the financial statements of the semi-autonomous and autonomous entities ordered by Pakistan's Auditor General under the directions of the Majlis-e-Shoora act and the president of Pakistan.

- It is also the responsibility of the committee to ensure that whatever money is given to any particular ministry, if that ministry has spent more than that amount, then the committee will investigate the matter and will also look at all the issues that make these coasts huge.

- If the assembly is disbanded then the incomplete effort of the preceding agency is handed over to the newly formed committee.

The chairman of the PL meets with the representatives of the concerned agencies of government whose accounts are being reviewed. However, Pakistan is the only country where the member of the opposition party becomes the chairman of any crucial committee and the PPP government started this tendency. Hence, the role of this committee is primarily pre-determined, meaning that it cannot implement or announces a decision. Committee sends its recommendations to the district council, provincial assembly, and the parliament of Pakistan but it cannot make sure of its implementations. The PAC proceedings are open to the public and media and Pakistan's auditor general acts as the PAC advocate in the proceedings of this committee (Sirmed, 2019).

Therefore, PLC plays an important role in budgeting and monitoring the country's revenue and expenditure. But unfortunately in Pakistan, it has not remained much active because it was not established at district and provincial levels. however, efforts are underway to develop or improve the PAC committee in Pakistan such as the government of Pakistan have sent some members of the committee abroad for training and 2 million dollars are also allocated to the committee by the world bank so that Pakistan tried to build the capacity of the PAC members (Sirmed, 2019). 


\section{Committee on Government Assurances}

The Committee is comprised of extreme of 16 members. It is a domestic committee and is elected via the assembly. Besides, automatically the minister of "Law, Justice and Parliamentary Affairs" is added to the committee as a member. However, from time to time the committee closely monitors governmental grants, commitments, special subsidies, and assurances of any kind by the government or any minister, as its name implies. The committee also examines the extent to which these promises have been fulfilled and kept (Zaka, Green, \& Malik, 2015). It also examines by this committee whether these commitments have been fulfilled within the stipulated time frame or not. The Ministers provide or give the main functions for the committee on the floor of the House since occasionally (Ahmad, 2017). These functions are to proceed with announcement of the capacities, the responsibility of the government, scrutinized assurances, and commitments of the governments.

\section{Committee on Privileges and Rules of Procedure}

Committee on Privileges and Rules of Procedure consists of 22 members. Furthermore, automatically the Minister for "Law, Justice and Parliamentary Affairs" is also one of the appointed members of this committee. The Speaker of the House referred the functions to the 'Committee on Rules of Procedure and Privilege that are to consider the conduct of business in the assembly, to consider the procedure in the Assembly, and to scrutinize questions of privileges. This committee does work according to the following principles:

- The committee is obliged to consider the conduct of business its procedure and matters in the assembly and will make a necessary recommendation.

- This committee also examines the privileges which give to the speaker of the assembly and make it sure with the use of resources that these privileges are not being violated. If there is a violation, the committee reviews the nature and factors of the violation or breach that led to the situation. Besides, the committee makes essential advice where gaps need to be filled.

- The committee may criticize the procedure of the assembly and provides effective recommendations and suggestions with formulating guidelines to make its methodology more efficient and effective.

\section{Committee of House and Library}

House and Library Committee consisted of 13 members which are elected by the assembly. Deputy Speaker is the chairperson of the committee, while Housing and Works minister becomes the member of this committee automatically. This committee contracts the difficulties involving the matters pertaining to the library. However, there are some of the responsibilities that fall on this committee and these are the following:

- This committee is responsible for resolving the issues related to members of the assembly residential accommodation, issuance of admission cards for questions and galleries.

- Ensuring and overseeing the provision of accommodation, catering and other facilities is also an important responsibility of it.

- This committee is also responsible for maintaining the library, research Centre development, enriching library contents, and automation. So that resources remain available easily and make it convenient for the members of the Parliament.

\section{Committee of Business Advisory}

Business Advisory Committee consisted of at least 19 members and was formed via the reciprocated consent of the leading light of opposition and leader for the house at the beginning of the term of the government. The committee for the formation of this committee is chaired by the speaker automatically. Through the discussion of the leader of the House, Speaker referred the tasks to the Business Advisory Committee. The main function of this committee is to propose and implement the time frame of all governmental affairs. The task is to set aside time for other business and government bills to be discussed and phased out.

\section{Some Provisions concerning about Standing Committees}

Sharing the membership of the different standing committees is a rule of thumb. However, it is at the decision power of the speaker assembly that he could recommend any member of the assembly as chairman of the standing committee. However, if the chairman of the committee is appointed as a minister, he will be disqualified automatically from the chairmanship of the committee while no minister can be nominated as the chairman of the committee. In addition, if 
less than $1 / 4^{\text {th }}$ of the total embers of the committee confirm their presence, then a committee meeting can be called. "This minimum criterion is termed as Quorum of a meeting" (Niazi, 2013).

If any member of the committee remains absent for three consecutive days from the sessions of the committee, so on the motion started by other members of the committee he or she will be removed from the committee automatically. Therefore, all the subjects under the committee consideration will be settled by the system of the majority of voters. Though, sometimes in the absence of the committee chairman, a situation arises in the committee where the number of the votes is equal then the chairman makes the final decision in this matter. It is known as "Deciding Vote" generally (Ahmad, 2017).

Standing committees have the power to increase the resources of their sub-committees and to give them full support. All sub-committees are formed through standing committees in order to help them to carry out specific tasks effectively by checking them because these organizations lead to the job allocation and division of labour. Therefore, the sub-committees are dissolved after resolving the referred issue automatically. The committees also have the power to ask the governmental documents, records and papers. If the government, on security grounds deny to present governmental documents or records to the committee then the speaker assembly resolves this issue through his decision.

The committees may also all the observers once influential purpose of the question, so these observers might be professionals in the matters being investigated by the committee. However, during the interrogation, the chairman of the committee may ask other members of the committee to ask witnesses as well. All the shreds of evidence presented to the committee by the witnesses are available before the members of the committee. Secretary maintains a record of the committee's activities and keeps the committee's report confidential before submitting it to the assembly (Zaka, Green, \& Malik, 2015).

A committee can submit the state results with recommendations to the government but with the permission of the speaker before submitting it to the assembly. The statement must be offered within 30 days and when the report is tabled in the assembly, and then the chairman of the committee demands the speaker assembly to direct the house to consider the report. However, if the assembly is not in session, then the chairman of the committee can ask about publishing the committee report to the speaker assembly before presenting it to the assembly.

\section{Other Committees}

There are many other committees that are very helpful to parliament in fulfilling its mandate. These are the following:

\section{Select Committees}

The Select Committee consists of the chairman of the concerned standing committee and the minister in the custody of the agency to which the notice belongs. However, the assembly fixed or determines the members of the committee.

\section{Special Committees}

The assembly formed a special committee in response to a motion to resolve a particular issue. However, the work of this committee and its composition is also determined by this motion (Niazi, 2013). The Select Committee's Chairman a Minister may be elected. A Special Committee might be chosen by the Assembly to takes out functions or responsibilities by way of might be particular in the action or activity. On $22^{\text {nd }}$ October 2008, a determination was accepted on the term of fourteen-point determination and set up the exceptional committees. Twelve special committees were founded by the thirteenth national assembly. Their details are under the following: 


\begin{tabular}{c|l|}
\hline Sr \# & \multicolumn{1}{|c|}{ Name of Special Committees } \\
\hline 1 & This Special committee to deliberate the rise in products of petroleum prices \\
\hline 2 & This Special committee on energy shortage and its crisis \\
\hline 3 & This Special committees to supervise the resolution implementation of all parties conferences \\
\hline 4 & $\begin{array}{c}\text { This Special committee on delay in all flights including grounding of the aircrafts of PIA and } \\
\text { Hajj flights }\end{array}$ \\
\hline 5 & This Special committee to examine the threats to media personnel and journalists \\
\hline 6 & Special committee to look into the matter of delay in construction work \\
\hline 7 & This Special committee on law and order situation in Baluchistan and Karachi \\
\hline 8 & This Special committee on the Goals of Millennium development \\
\hline 9 & $\begin{array}{l}\text { Special committee to look to the alleged allotment of plots to the offices of ministry of } \\
\text { ministries affairs }\end{array}$ \\
\hline 10 & This Special committee on domestic and Foreign loans \\
\hline 11 & Parliamentary forum on the rights of child \\
\hline 12 & This Special committee on ministry persons \\
\hline
\end{tabular}

Source: (Niazi, 2013) (Palonen M. , 2016)

\section{Conclusion}

In short parliamentary committees are also the sub organs of the National Assembly of Pakistan which help and assist the legislature in the legislation process. As long as committees work properly, the parliament will be successful at its core. However, committees involved must keep watch on errors in actions of different areas of intelligence. Besides, the actions committed by civil services seniors must be observed by committees in the parliament. Members of committees must hand-in their analysis when it's due to implement on real life matters. Powers in political can only be available for use for the cabinet and the opposing party must look into it in order to keep a balance of power for the interests of the public. Noting, analyzing the work done by committees in standing represent the effectiveness as well as the connection between committee members that the roles they have are quite significant. Therefore, to make itself a rule for Pakistan, all those inside the Parliament Houses should proceed with legislation which involves thirteen or twelve stages, involving reading it three times at Senate as well as National Assembly, and after that the president will pass an approval. This procedure must be regulated through the constitution of processes in the House involved as well as the Constitution of Pakistan.

\section{References}

Ahmad, T. (2017). National Parliaments: Pakistan. UK: The Law Library of Congress, Global Legal Research Center.

Assembly, N. (2017). The Report of the Parliamentary Committee on Electoral Reforms on Election Bill. Islamabad: The National Assembly of Islamic Republic of Pakistan.

Chang, B., \& Ramshaw, G. (2019). Effective Functioning of Standing Committees on Human Rights in Punjab and KPK Provinces . Lahore: Democracy Reporting International .

Cheema, F. S. (2020). Public Sector Financial Accountability:The Role of Public Accounts Committee in Pakistan. Islamabad: ecosai-circular-spring-issue-2020-16.cdr. 
Cheema, G. A. (2018). Parliamentary Committee System in Provincial Assembly of Punjab- Myth of Executive Accountability. Pakistan Institute of Parliamentary Services, 5 (7), 6-18.

CPDI-Pakistan. (2005 ). Parliamentary Alert No. III: Performance of the National Assembly of Pakistan (2004-05). Islamabad: Centre for Peace and Development Initiatives, Pakistan (CPDI-Pakistan).

Hasan, M., Hanif, M., \& Khan, M. N. (2009). Eighteenth Amendment Revisited. Islamabad: Islamabad Policy Research Institute.

Mahmood, T. (2015). A Comparative Analysis of the Functioning of the Senate in USA and Pakistan. A Research Journal of South Asian Studies, 30 (2), 265-280.

Niazi, K. H. (2013). Rules and Procedures and Conduct of business in the National Assembly 2007. Islamabad: National Assembly of Pakistan.

Palonen, M. (2016). The Politics of Parliamentary Procedure: The Formation of the Westminster Procedure as a Parliamentary Ideal Type (2 ed.). Berlin, Toronto: Barbara Budrich.

PILDAT. (2013). 5 year of 13th National Assembly of Pakistan 2008-2013. Islamabad, Pakistan: Pakistan Institute of Legislative Devellopment and Transparency.

Raza, R. (2009). Pakistan in Perspective, 1947-1997 (illustrated, reprint, revised ed.). Lahore: Oxford University Press, The University of California.

Sirmed, M. (2019). Committee System in Parliament of Pakistan. Islamabad: National Project Manager Strengthening Democracy through Parliamentary Development inStrengthening Democracy through Parliamentary Development inPakistan (SDPD) ProjectPakistan (SDPD) Project(UNDP / IPU / Parliament of Pakistan)(UNDP / IPU / Parliament of.

Tasleem, A. (2013). Preliminary Research on Parliamentary Committees. Karachi: Manzil Pakistan Oxford University Press, UK.

Valentine, E. (2010). Pakistan Parliamentary Libraries: A Historical Excursion and Hopes for the Future. LIBRARY TRENDS, 58 (4), 527-548.

Yamamoto, H. (2007). Tools for Parliamentary Oversight: A Comparative Study of 88 National Parliaments. Switzerland: Inter-Parliamentary Union .

Zaka, M. R., Green, Z. A., \& Malik, D. u. (2015). Discover the Parliament of Pakistan: Pakistan Institute for Parliamentary Services Youth Guide. Islamabad: USAID - Pakistan Legislative Strengthening Project. 